\title{
YITZHAK OREN'S FANTASTIC SCIENCE: TWO STORIES
}

\section{Glenda Abramson*}

Abstract: Until recently, Israeli literary scholars have dismissed fantasy as insignificant for ideological and political reasons. Yet there has been a long tradition of fantasy in Jewish literature. Now, thanks to the Bulgarian philosopher Tzvetan Todorov's precise conceptualisation of fantasy as a distinct literary genre, we are able to define works of the Fantastic with greater clarity. The Hebrew writer who most immediately comes to mind with respect to fantasy is $S$. Y. Agnon, whose works are replete with ghosts, magic, strange creatures and events. In this article I examine two stories by one of his younger contemporaries, the Israeli author Yitzhak Oren from the point of view of Todorov's generic classification. I ask whether defining Oren's stories according to Todorov's generic system helps us to read them. I believe that applying Todorov's categorisation to Oren's fiction certainly determines the way we read it and that this has implications with regard to other Hebrew authors, Agnon in particular, and to the work of some younger Israeli experimental writers.

There is a strange belief that modern Hebrew literature avoids fantasy, or at least that it has done so until recently. Perhaps the genre of fantasy was not recognised because it did not suit the criteria of the arbiters of the Hebrew literary canon as it was being formed at the turn of the 20th century, perhaps because of the perceived nature of fantasy at that time. The fantastic genre is still often characterized as escapist, nonserious, and 'minor," exiled to the 'edges of literary culture.' ${ }^{2}$ Moreover, these canonisers saw Hebrew literature from the start as committed to the development of the national consciousness, to an extent a guide for social thinking, about which it had to be explicit not obscure. Realism was, therefore, the reigning genre. Israeli literary scholars have, until recently, similarly dismissed fantasy as insignificant for ideological and political reasons. In its early years Israeli literature was recruited into the enterprise of nation building and the writers were obliged to address concerns of Israeli individual and social identity. Literary characters were rarely distinct from their national and social origins, unlike characters in fantastic fiction. In any case the

\footnotetext{
* Professor of Hebrew and Jewish Studies, University of Oxford; Editor of Journal of Modern Jewish Studies. Email glenda.abramson@stx.ox.ac.uk

${ }^{1}$ Carter Wheelock, 'Fantastic Symbolism in the Spanish American Short Story', Hispanic Review 48:4 (Autumn, 1980), 416.

2 Ásdís Egilsdóttir, 'The Fantastic Reality: Hagiography, Miracles and Fantasy', http://www.dur.ac.uk/medieval.www/sagaconf/asdis.htm
} 
writers of the third and fourth aliyot had largely, although not exclusively, been influenced by Soviet socialist realism. Barukh Kurzwell, the leading Israeli scholar of Hebrew literature, himself of Central European origin and broadly versed in European literatures, frequently berated the young Hebrew literature when it strayed into European aesthetic territory. According to Ortsiyon Bartana, who has written the only comprehensive study of Israeli literary fantasy, the creation of a specific ideal of 'normalisation' in fiction - meaning the apprehension of fiction as reflecting a normal society - strongly influenced the marginalisation of fantasy after the establishment of the state. ${ }^{3}$ Similarly, those authors who, for whatever reason, did not fit into the collective framework, or those who failed to comment about the 'enterprise', including writers of fantasy, were marginalised.

In fact, there has been a long tradition of fantasy in Jewish literature, which is not surprising considering the prominence of mysticism in all branches of Jewish culture. Rabbi Loew's Golem was a fantastic creation long before Dr Frankenstein's and it has been proposed that even Herzl's futuristic Altneuland is a work of utopian fantasy. Moreover, there is an historical awareness in Hebrew literature of the miraculous, primarily realised in the allusiveness of modern texts to the biblical text. Modern fantasy in any case has its roots in myth, mysticism, folklore, fairytale and romance.

We are now able to qualify works of the fantastic, thanks to the Bulgarian philosopher Tzvetan Todorov's precise conceptualisation of fantasy as a distinct literary genre. ${ }^{4}$ According to Todorov, the Fantastic requires the fulfillment of three conditions. First, the text must oblige the reader to consider the world of the characters as a world of living persons and to hesitate between a natural or supernatural explanation of the events described. Second, this hesitation may also be experienced by a character as well as the reader; third, the reader must reject allegorical as well as 'poetic' interpretations. ${ }^{5}$ In short, the Fantastic is characterized by a simple narrative stratagem: putting supernatural events into a realistic narrative as if they were true. Todorov distinguishes the Fantastic from other modes or sub-genres, one being the 'fantastic-

\footnotetext{
${ }^{3}$ Ortsiyon Bartana, Hafantasia basifrut dor hamedina [Fantasy in the literature of the generation of the state] (Tel Aviv: Papryrus/Hakibbutz Hameuchad, 1989), 40.

${ }^{4}$ Tzvetan Todorov, The Fantastic: A Structural Approach to a Literary Genre, trans. Richard Howard and Robert Scholes (Ithaca: Cornell University Press, 1975).

${ }^{5}$ See Todorov, The Fantastic, 33.
} 
uncanny' and another, the 'fantastic-marvellous...the class of narratives that are presented as fantastic and that end with [the reader's] acceptance of the supernatural. ${ }^{, 6}$

Modern fantasy has moved beyond 19th-century romantic models of the supernatural. In Hebrew literature it acquires ideological accretions that may, in intentionality, rather than modality, cause it to exceed Todorov's qualification. Bartana's definition of fantasy in Israeli literature is more inclusive than Todorov's scheme. For Bartana, fantasy is 'every story that describes a seemingly real world, that creates alternative relationships with the real world well known to the reader. ${ }^{7}$ This broad definition includes myth, allegory, fable, metaphysics and the absurd. 'Every description of the supernatural that appears in a story is sufficient for the story to be defined as fantastic... therefore I shall use the term 'fantastic' here as a catch-all for the entire system of non-realistic stories. ${ }^{98}$ In one respect Bartana's definition is crucial in its application to the relationship between Hebrew literature and Israeli culture. He refers to the 'secular myth' of Zionism:

This myth came to herald the renewal of the biblical kingdom, the actuality of redemption, independence after two thousand years of exile and above all, to give a response to the destruction, Holocaust. This was a secular myth, distinct from the symbols known as Jewish tradition. ${ }^{9}$

He includes the 'metaphysical' story in his definition of the Fantastic, as the modern realisation of a myth. The subversive implication that Zionism is somehow linked with fantasy has real political connotations in Israel, rather than relating only to a theoretical or aesthetic argument. However, this idea has not been developed in Hebrew writing that can be deemed to belong to the genre of fantasy.

On the other hand, it may be that in modern Hebrew literature, fantasy is a means of avoiding direct confrontation with difficult topics; it has been used by canonic authors to convey controversial ideas in palatable form. For example, fantasy has been used

\footnotetext{
${ }^{6}$ Todorov, The Fantastic, 32.

${ }^{7}$ Bartana, Hafantasia basifrut dor hamedina, 32.

${ }^{8}$ Bartana, Hafantasia basifrut dor hamedina, 32.

${ }^{9}$ Bartana, Hafantasia basifrut dor hamedina, 19.
} 
more extensively from the 1980s as a new way of expressing the Holocaust experience, by 'crossing certain limits' that had hitherto been largely avoided in Israeli literature. ${ }^{10}$ This renewed encounter required a departure from the prevailing cultural norms which regarded as taboo the representation of the concentration camps by those who had not experienced them. ${ }^{11}$ The fantastic is a narrative strategy to counter the taboo by holding the real at arm's length while contributing to the Holocaust discourse.

The Hebrew writer who most immediately comes to mind with respect to fantasy is Agnon, whose works are replete with ghosts, magic, strange creatures and events. However, Bartana scarcely mentions him, probably because Agnon's stories often present a moral message whose importance surpasses its means of transmission. For example, what is Agnon's 'Im kenissat hayom' (At the Outset of the Day)? An example of fantasy, an example of the surreal, a philosophical conundrum or a combination of all three which technically, according to Todorov, preclude each other? Todorov's demarcations of fantasy help us in distinguishing it from surrealism, a genre to which Agnon's stories are more likely, at first glance, to belong. Yet despite their obvious similarities, primarily their departure from realism, fantasy and surrealism differ in intent. In Agnon's story a man who has been away from home returns after suffering the privations of a war. His former acquaintances are dead or have moved away. In his arms he carries his small daughter whose clothes have been burnt off her back during the conflict. On the eve of Yom Kippur, he stands outside and gazes at, but does not enter, the synagogue in which he had once written Torah scrolls. A straightforward realistic narrative, it seems, but it does provoke a degree of hesitation. Strange characters appear on the scene; the protagonist's beloved late teacher's house is now inhabited by ghosts, the child clothes herself with her long hair and utters gnomic words of wisdom. The story could comply with Todorov's definition of the Uncanny where, he says, events appear to be rational - as products of the protagonist's dream or delusion, for example - but are 'in one way or another, incredible, extraordinary, shocking, singular, disturbing or unexpected. ${ }^{12}$ The

\footnotetext{
${ }^{10}$ Gilead Morahg, 'Israel's New Literature of the Holocaust: The Case of David Grossman's SEE UNDER: LovE', Modern Fiction Studies 45:2 (1999), 462.

${ }^{11}$ Morahg, 'Israel's New Literature of the Holocaust', 462.

12 Todorov, The Fantastic, 46.
} 
Uncanny is distinguished from other sub-genres of the fantastic by being associated with the past (previously experienced phenomena). ${ }^{13}$ In Agnon's story the familiar home has become unfamiliar and unknown, a quality of the uncanny (unheimlich), according to Freud, something familiar made strange by repression. The symbol of repression in Agnon's story is the genizah in the synagogue in which unwanted scrolls, some once written by the protagonist, have been discarded and forgotten - not least of all by the protagonist himself. Yet in this story, as in others by Agnon, the border between fantasy and morality tales is unclear. In this tale, the child represents the soul, unclothed because of the father's desertion of his home and, evidently, of his former piety. The tale is, then, an extended metaphor for loss: of home, family and faith, but technically it may qualify as Fantastic in its style and narrative content.

While the moral element predominates in Agnon's stories, however aligned to the Fantastic genre they may seem to be, this is less clear in the case of one of Agnon's younger contemporaries, the Israeli author Yitzhak Oren (1914-1997). In this article I examine two of his stories from the point of view of Todorov's generic classification. Oren's work is difficult both to place and to understand. The question I wish to address is simply whether situating it within Todorov's narrower and less culturespecific categorisation tells us how we should read it. Born in Siberia and raised in Harbin, Oren is virtually unknown in Israel. It is possible that his unusual path to Palestine, from East Asia rather than the Russian Empire, estranged him from his contemporaries. He was not a member of any of the aliyot, having arrived in Palestine in 1936 and was, therefore, not immediately identified with an ideological or literary group or journal. He began to publish in 1946, in Keshet, a journal that represented the Canaanite movement although Oren was by no means a Canaanite, while politically on the right. This might also have been a bar, at the time, to an Israeli author becoming canonic.

The reason for his obscurity is, therefore, not difficult to fathom. However, it is not because of an avoidance of the canonical subjects; quite the contrary, he commented on Jewish culture from its very beginnings and certainly saw himself as an advocate

\footnotetext{
${ }^{13}$ Jacqueline Eyring Bixler, 'Freedom and Fantasy: A Structural Approach to the Fantastic in Carballido's Las cartas de Mozar', Latin American Theatre Review (Fall, 1980), 17.
} 
for Jewish redemption in Israel, in fact as something of a secular prophet, using science to prefigure the messianic age. Yet his writing, filled with extraordinary erudition, that of an earlier, European, generation, is difficult, particularly in the context of the realism that dominated Hebrew letters until the last three decades of the 20th century. His stories are largely delocalised although nominally set in Israel, and populated by characters bearing Jewish names. Oren was, in Gershon Shaked's words, positioned between the generations, between the styles and the topics, a comment that reveals much about the constitution of the literature of the time. ${ }^{14}$ Oren has been called a surrealist and a materialist, a realist and a magic realist, a fantasist and, at times, even an expressionist. He has been compared, with some justification, to Kafka and Borges.

A prevalent metaphor in Oren's writing is the world of physics and mathematics. Almost uniquely among Israeli writers he admires scientific and technological achievements, with scientific ideas acquiring effective symbolic colouring in his work. Avraham Huss notes Oren's fondness for ideas adopted from science - particularly modern physics. ${ }^{15}$ One of his major protagonists in a sequence of stories is a physicist. Oren intersperses his narratives with passages accurately describing physical phenomena and mathematical arguments. Science for Oren is more than a trope. He believes that modern culture involves the conversion of ancient myth to modern science and that the Jews will achieve redemption through cosmic understanding. ${ }^{16}$ In his overall schema, developed through his fiction, science therefore represents the negotiation of an ancient culture with the modern, technological world. The conceptual thread in many of his stories is his perception that humanity is able to alter its character through science and technology if they are used correctly. Oren believes that the 'repair of the world' can be attained through knowledge and reason, rather than myth and religion. Science, according to him, is able to correct the cosmic error and physics has defeated theology. ${ }^{17}$ On the other hand, his very philosophy is

\footnotetext{
${ }^{14}$ Gershon Shaked, Hasipporet ha 'ivrit 1880-1980, 3 (Jerusalem/Tel Aviv: Keter; Hakibbutz Hameuchad, 1988), 168-169.

${ }^{15}$ See Max Knight, ed., The Imaginary Number: Short Stories by Yitzhak Oren, trans. various (Berkeley, California: Benmir Books, 1986), xvii.

${ }^{16}$ Interview with Yitzhak Oren: Sarah Katz, 'Yitzhak Oren, yotser poreh...' Makor rishon (September, 2007), 6-7. See also Leah Baratz, Monografiyah al odot Yitzhak Oren (Nadel) (Tel Aviv: Or Am, 2003) 69-71.

${ }^{17}$ Baratz, Monografiyah al odot Yitzhak Oren (Nadel), 71.
} 
satirical: his 'science' is a parody of scientific reason; despite his pseudotechnological language, it is either metaphorical or simply absurd, paradoxical and fantastic.

\section{'The Imaginary Number'}

Most of Oren's stories are autonomous and, like all good fantasy, they are ostensibly realistic while defying all existential logic. One such example is 'The Imaginary Number'. ${ }^{18}$ Whether the label Fantastic should be assigned to it is at first uncertain since it does not obey all Todorov's generic precepts. The imaginary (or complex) number, represented by the letter ' $\mathrm{i}$ ', is the square root of minus one. Mathematically it has a function, with the word 'imaginary' as a recognised mathematical term, employed by scientists and mathematicians, and it is also Oren's sly reference to the incongruous impossibilities within his own text. He has taken this 'imaginary number' enigma as a metaphor for a material reality that has been denied. The story's proposition is that two men have been close companions since early childhood, they marry twin sisters, have families who are also close from birth, they have both bought identical plots of land, and yet one of the men, Benjamin, a physicist, has no recollection of the other man or of his life. ${ }^{19}$ This 'other', Mickey, who has returned to Israel after some time abroad, discovers that his plot of land no longer exists. On his behalf Benjamin visits the Custodian of Enemy Property, a fictional bureaucracy and, by citing the principle of the imaginary number, proves that the non-existent property in fact exists and it is subsequently restored to its owner. Nothingness has become being, in accordance with Leibnitz's appraisal of the complex number. ${ }^{20}$ The story is a dazzling tour de force, that refers, inter alia, to real mathematical and philosophical principles and to the word 'absurd' that was applied by mathematicians to the idea of the imaginary number, and which defines Oren's tale as well.

\footnotetext{
${ }^{18}$ Knight, The Imaginary Number, 1-14.

${ }^{19}$ This story is included in Oren's Masot Binyamin hahamishi [The adventures of Benjamin the Fifth] whose protagonist is the physicist, Benjamin. The title alludes to the other Benjamins in Hebrew literature, the original Benjamin of Tudela, his successor the nineteenth-century Israel Joseph Benjamin who travelled through Europe and the East in search of the lost tribes, and and Mendele's comic Benjamin in search of Sambatiyon.

20 'Imaginary numbers are a fine and wonderful refuge of the Holy Spirit, a sort of amphibian between and non-being.' Quoted in Edward Kassner, James Newman and James Roy Newman, Mathematics and the Imagination (Dover Publications Inc., 2003), 92.
} 
It was to the complex number's essence that the wisest mathematicians applied the adjective 'absurd'. But the use of the word 'absurd' with regard to the complex number's essence did not last long... The wise men of mathematics began to call the principle by the name 'imaginary number'. In addition to recognizing this implied surrender, 'imaginary' is delicate in contrast to 'absurd.' (8)

Oren's story incorporates mathematical terms such as 'variable function' and 'differential equation' which, if I understand them correctly, on the most basic level indicate the dependence between entities or variables. The story is concerned with independence achieved as a result of dependence. It was written in 1956, at a time when survivors of the Holocaust were still pouring into Israel - a fact mentioned at one point in the text. Mickey has returned to an unfamiliar home after having escaped the catastrophe abroad. This would place the story in Todorov's category of the fantastic-uncanny. In Oren's story, as in Agnon's, the familiar home has become unfamiliar and unknown, Freud's unheimlich, as mentioned earlier. Or perhaps Mickey is Benjamin's double. For Freud, the Doppelgänger is the archetypal figure of the uncanny, embodying the return of the repressed, in this case the repressed memory of exile, suffering and genocide. Either way, Oren's fantasy encapsulates the fate of the survivor rediscovering his past. The question is whether Mickey is Benjamin's delusion, or whether Mickey's past is the unlived or unremembered past of Benjamin, whether the two men are the same man, with the variable being the fate of the one in Europe and the other in Israel. Since the story discusses the product of positive and negative numbers, perhaps the two men represent the opposite poles of a single person with differential fates.

The lawyer in the story is one Mr Necker, a reference to the Necker cube, which is an optical illusion in which a two-dimensional drawing of a cube appears simultaneously to protrude from and intrude into the page, that is, that a single form assumes two representations. The Necker cube 'splits into two timelines which are presented alternately. ${ }^{21}$ In mathematical terms ' $i$, the virtual dimension in which these two time

\footnotetext{
${ }^{21}$ Alex Comfort, Reality and Empathy: Physics, Mind, and Science in the 21st Century (Albany: SUNY Press, 1984), 67.
} 
lines diverge is, in fact an imaginary number in Boolean algebra... ${ }^{22}$ However incomprehensible this may seem to the non-mathematician, for Oren it was an appropriate and clearly comprehended metaphor for the possibility of the divergence of timelines in the life of a single person. It would not be too fanciful to suggest that the single person in the story is Benjamin, represented by the first-person narrator, 'I'. For Oren, therefore, the imaginary number ' $\mathrm{i}$ ' is an existential proposition.

Despite these allusive games, on the face of it 'The Imaginary Number' is a realistic story: it has no ghosts, magic, vampires or demons, only a real mathematical principle. Yet curious effects in the story provoke the reader's hesitation: the eyes of Mickey, the visitor, turn from grey to blue and his face is a replica of mathematical form: '... a strand of his hair grotesquely shot out horizontally from his triangular face, giving his countenance a shape resembling the mathematical symbol for the square root $V^{\prime}$ (3). In addition, Benjamin's inexplicable amnesia about him, and the list of judgments given by the 'Deputy Attorney General for the State of Israel' at the story's end (a satirical element, for satire can be linked to fantasy), in addition to the fictional bureaucracy - all these shift the story from reality to fantasy. Much of the modern fiction that we call fantastic does not qualify as such because it departs from the strict standards of what is supernatural or literal, usually by being metaphorical or symbolic. $^{23}$ There is certainly an element of metaphor in the appearance of a mathematical principle in 'The Imaginary Number' yet it is difficult to see precisely what the metaphor entails.

The question is whether there can be fantasy without the strictly supernatural, only the unnatural which Todorov does not define. This would include elements of realism, the Fantastic, the imaginary and the absurd. In the story Todorov's principle of hesitation could be somewhat disrupted when Benjamin's wife, who had initially treated Mickey's history and family with disbelief (the disbelief necessary to the definition of the Fantastic), 'now, in her old age she discovered a 'sister', a twin sister at that!' (7) Oren leaves the problem of the wife's feigned belief or honest disbelief

\footnotetext{
${ }^{22}$ Comfort, Reality and Empathy, 67. Boolean algebra is a system of symbolic logic devised by George Boole; used in computing.

${ }^{23}$ Wheelock, 'Fantastic Symbolism in the Spanish American Short Story', 415.
} 
unresolved. Yet in 'The Imaginary Number' the characters themselves are mystified by the 'uncanny [muzar] stranger' and the reader's hesitation is therefore justified.

\section{'Anti-metamorphosis, 24}

A Necker cube appears on the banner appearing in M. C. Escher's series of lithographs entitled 'Metamorphosis I'. Metamorphosis is an element of fantasy. This leads me to the second story in my discussion of Oren, his 'Anti-metamorphosis', about a man, Yitzhak Hogam, who wakes up one morning to find that he has been turned into a dog. In a short introduction the narrator (apparently a scientist) suggests that the reader first read Kafka's 'The Metamorphosis' (1915).

Oren's intertextuality or, rather, hypotextuality, renders his fictional structures insecure and inchoate, 'decoherent' to use Shaked's term. ${ }^{25}$ In various modified forms, inter- or hypotextuality as a literary device is one of the most significant phenomena in modern Hebrew literature. The reader of Hebrew secular texts is accustomed to polysemous reading in interpreting a work. Enlightenment poets suggested this technique as a code for the understanding of their works, directing their readers towards the concurrent reading of their poem together with the biblical passages to which they referred. Readers could not fully appreciate the new poem unless they read both sources side by side. In this peculiar duality the shadow text imparts as much 'meaning' as the new text overwritten it. ${ }^{26}$

In Israeli literature this inter- or hypotextuality expresses Israel's cultural identity. Its most significant function is to reflect the strong links between the biblical text and modern Jewish consciousness even - perhaps especially - among the secular writers. Hebrew writing has never wholly strayed from its textual ontological nature. Modern or not, its overriding framework is text. While many modern Hebrew writers constitute their identity through recourse to traditional texts, others, including Oren

\footnotetext{
24 'Ha'antimetamorfosis' in Yitzhak Oren, Pnei dor vakelev [The face of a generation and a dog] (Jerusalem: Ogan, 1968), 204-225, trans. Philip Simpson, The Jewish Quarterly (Winter 1989-1990), 14-24.

${ }^{25}$ Shaked, Hasipporet ha ivrit 1880-1980, 170.

${ }^{26}$ See Tova Cohen, 'The maskil as lamdan: the influence of Jewish education on Haskalah writing techniques' in Glenda Abramson and Tudor Parfitt, eds., Jewish Education and Leaning (Reading: Harwood Academic Publishers, 1994), 61.
} 
and, for example, his contemporary poets Natan Zach and Dan Paggis, add elements of world literature and scientific principles. Shaked, who does not assign the judgment of 'inchoate' to them, argues that Oren's text illuminates the Kafka original 'from a new point of view. ${ }^{27}$ It may not be too fanciful to suggest that this textual duality echoes Oren's motif of the double inasmuch as each of the two texts is illuminated by the other.

'Anti-metamorphosis' falls into the category of 'fantastic-marvellous' according to Todorov's formulation. A man becomes a dog in a real, recognisable world yet there can be no readerly hesitation. In fact, Oren himself reinforces Todorov's definition by writing (in the story),

It could be claimed that the initial transformation of Yitzhak Hogam into the form of a dog was in itself an unprecedented phenomenon, a kind of miraculous event in which the laws of nature played no part. Such being the case... there is no point in seeking a scientific explanation for this specific occurrence. (22)

He goes on in the story to refute this proposition with paragraphs of pseudo-science.

The story begins with a direct parody of Kafka's 'Metamorphosis': Yitzhak Hogam wakes up in the morning to find that he has become a dog. Despite his transformation, unlike Gregor Samsa, Hogam actually reaches his office where he holds the significant title of the Chief Assistant to the Controller of Universal Creativity. The grandiose title recalls Kafka and his fictional bureaucracy. Throughout his oevre Oren has parodied ludicrous bureaucracy, no doubt calling upon his own lifelong experience as a civil servant. The title of his fictional office illustrates his conviction that the creation of material and fictional worlds is indistinguishable. Through fiction various threads in human culture can be linked. Oren's writing ranges through these links, making logically impossible connections between established works of art and their creators, in the case of this story, Kafka, Bialik, Josephus, Engels and Charlie Chaplin. It seems that Oren's characters have no existence except through a mutuality

\footnotetext{
${ }^{27}$ Shaked, Hasipporet ha ivrit 1880-1980, 168.
} 
of existence. He links literary characters to each other with the aim of creating a model of the endless unity of the fictional world, almost as if he is summoning a parallel universe of fiction living by its own laws. In Oren's quasi-kabbalistic mode of thought, each new work of the intellect, be it literary or scientific, repairs the known world.

The second section of the story is devoted to the correspondence between Hogam's wife and the Department of Pensions Allocations since there is some problem about paying a pension to a dog. Incidentally, Hogam's lawyer is called On Zafrir - which may be an allusion to Bialik's poem 'Zafririm' that celebrates strange, ephemeral creatures, undefinable in the real world. Hogam's correspondent in the Department of Pensions Allocations is Tamar Ralbag, whose acronymic name is that of Levi ben Gershom, better known as Gersonides or the Ralbag (1288-1344) a French rabbi, philosopher, mathematician and astronomer/astrologer who attempted to approach religion through reason and believed that reason and the Torah need not be in opposition. He is a fitting alter ego for Oren.

Unlike Samsa, who is mystified by his new status, Hogam is contented in his canineness. He encounters a female dog, signifying the 'other', a central theme of Todorov's Fantastic, representing the libido or sexuality. 'Desire as a sensual temptation finds its incarnation in several of the most common figures of the supernatural world and most especially in the form of the devil. To simplify, one might say that devil is merely another word for "libido". ${ }^{28}$ This encounter leads to Hogam's downfall. He is impounded for biting the female dog's human. Like Kafka's hunger artist, he refuses to drink the water provided for him in his prison, although he suffers 'a thirst... no amount of water could quench... The thirst was the thirst of longing that consumes the soul of all those expelled from the Garden of Eden,' that is, the sense of perfection Hogam has achieved as a dog. The devil libido has removed Hogam from the Garden of Eden. In her essay on Oren, Giulia Miller equates desire

\footnotetext{
${ }^{28}$ Todorov, The Fantastic, 127.
} 
and the Garden of Eden, so that by aspiring to one Garden of Eden, Hogam loses another. $^{29}$

While in prison Hogam finds that, against his will, he is able to utter the word 'Mother'. In an inversion of the psychological norm, the dog Hogam's malady of speech signifies a regression, an anti-metamorphosis: while explaining the scientific principle of regression, the narrator confounds us by his analysis of Hogam's regression to the former state of humanness, as a result of trauma. Hogam's inner beast in this case is a benign creature, loyal and truthful, subject only to his senses. Just as trauma may reduce a man to the level of a beast, trauma has degraded Hogam to the level of a human. The word 'Mother' could also be taken to indicate Hogam's regression to childhood, but it is, instead, a further allusion to Kafka's Gregor Samsa who, after his transformation, appeals to his mother who is backing away from him in terror, "“Mother, mother," said Gregor softly, looking up at her.,30

Hogam the talking dog becomes a freak phenomenon, a performer, discoursing on politics and philosophy, and he dies onstage after a live public performance. This reminds the narrator of the last scene of Charlie Chaplin's Limelight and he asks: 'Is this not the one role shared by philosophy and art, to reveal and create the hidden threads that join creation to creation and creator to creator?' This indicates a perfect cosmic unity, with various threads in human culture linked through literature. In 'The Imaginary Number' Benajmin claims that the square root of -1 proves that what apparently has no existence does, in fact, exist. Oren comments, 'I claim that a human composition has an independent existence of its own, within the process of creation of the organic inanimate world... Raskolnikov is an actual, independent entity... an actual fact in the consciousness of human society in which he was created. ${ }^{31}$

There are similarities and differences in the two accounts of metamorphosis. For example, Hogam, unlike Samsa, revels in his new-found animality which brings a heightened sensuality to his life and release from work and family pressures. Unlike

\footnotetext{
${ }^{29}$ Giulia F. Miller, Unpublished Ph.D. thesis: The Marvellous and the Fantastic in the Works of Yitzhak Oren, 28. I wish to thank Dr Miller for allowing me to read her chapter on 'Anti-metamorphosis.'

${ }^{30}$ Franz Kafka, 'The Metamorphosis', 1915. The Metamorphosis, trans. and ed. Stanley Corngold (London/NY: WW Norton, 1996), 14.

${ }^{31}$ Katz, 'Yitzhak Oren', 2
} 
Samsa, who enjoys music and art, Hogam realises that 'life and life only is the purpose of life.' Like a dog, life is to be lived by instinct, the appreciation of pleasure and the renunciation of deception. The dog bites when it hates and licks when it loves. For Hogam this is the ultimate freedom. In Kafka's story Gregor's parents and sister despise and eventually kill him. Hogam's wife and daughter love and pet him and eventually profit from him. Samsa is ultimately emasculated, his power being devolved to, and then assumed by, his sister Grete. Hogam, the father and breadwinner, willingly cedes his power to his daughter Dafna, allowing her to confine him in a dog collar and leash. The father has surrendered his power to his women although he remains responsible for their sustenance through his pension.

One of the freedoms Hogam assumes is that of marking his territory with urine, an action he performs without human self-consciousness. He obeys Kafka's injunction to 'Water the ground as much as you can. ${ }^{32}$ In fact, in the act of urination, Hogam is inscribing his new self in nature, on the earth's canvas, just as the author, Oren, inscribes him on the page. 'Hogam lives as we have described in these paragraphs. ${ }^{33}$ Unlike the young dog's shocked response to the seven dancing dogs in Kafka's 'Investigations of a Dog': 'they were standing on their hind legs, uncovering their nakedness, blatantly making a show of their nakedness... as though it were a meritorious act', ${ }^{34}$ Hogam's new nakedness signifies a freedom from behavioural constraints, leaving his human self far behind. This is performed symbolically by the shedding of his tie.

The theme of performance leads the reader to other of Kafka's stories: Josephine the mouse singer, also an animal, the seven dancing dogs in 'Investigation of a Dog' (with which Oren's story has some affinities), and the hunger artist. Kafka was concerned that his German held traces of his parents' Yiddish, that he mauschelned. In Oren's story is it the power of speech itself rather than the form it takes, that ends his life. Overall, 'Anti-metamorphosis' is a reading against the Kafka original (as directed by the narrator in his introduction) in the sense of the impossibility of

\footnotetext{
${ }^{32}$ Franz Kafka, The Great Wall of China and Other Pieces (London/Edinburgh: Morrison and Gibb Ltd., 1946), 20.

${ }^{33}$ Oren, 'Ha'antimetamorfosis', 20.

${ }^{34}$ Franz Kafka, Complete Stories, trans. W. and E. Muir (New York: Schocken, 1971), 283-4.
} 
perfection represented by the metamorphosed self one way or the other. For Samsa, life cannot continue as a bug; for Hogam, to regain human qualities is regressive.

What is the significance of all these diegetic pyrotechnics? Shaked deems the story to be mere entertainment and for Todorov it would be an example of the "fantasticmarvellous.' Yet is it, after all, an allegory? Or a political comment derived from the title of the collection in which it appears, Pnei dor vakelev (the face of a generation and a dog), itself a reduction of the talmudic dictum that 'the face of the generation will be like the face of a dog' (Sotah 49b) meaning that in its expressionlessness the face of the generation will be unable to indicate shame, or that like a dog it is unable feel shame. Yet this is not relevant to 'Anti-metamorphosis' since Hogam represents nobody but himself and, rather than shame, his transformation brings him a measure of exhilaration. If it is an allegory, none of Todorov's definitions can be applied, by his own judgement that argues that allegory and fantasy are in opposition. The inherent duality of allegory cancels out the hesitation that is the defining characteristic of fantasy and destroys the 'truth' or 'literality' of the story. Yet Oren, as we have seen, likes dualities. ${ }^{35}$

Like the Hunger Artist, Hogam eventually becomes a showman or a showdog. $\mathrm{He}$ enjoys the fame and financial rewards. If this aspect of the story is indeed allegorical, and Hogam represents the artist, his transformation may suggest the shedding of all human accoutrements, his job, his possessions and his family in order to be recreated as an artist. He is, after all, the chief assistant to the controller of universal creativity. However, the satire implied in that title militates against the seriousness of an allegory of an artist's life. In 'Anti-metamorphosis', unlike 'The Imaginary Number' there is no reader's hesitation, since everything is abnormal and bizarre. For example, Hogam's secretary is terrified - but by the dog, not by her boss's transformation. Todorov has described Kafka's fiction as a 'generalized fantastic' that overcomes the worlds both of the story and the reader, a definition that can be applied to Oren's story. ${ }^{36}$ In Bartana's view Kafka's stories are interpreted in every variety of

\footnotetext{
${ }^{35}$ Common to many of his stories is a struggling and failing anti-hero who lives a double life: small and routine by day and heroic and romantic in imagination. The stories in this collection are generally not allegorical but examples of irony, black humour, fantasy and the grotesque.

36 'Themes of the Other' in Torodov, The Fantastic, 139.
} 
possibility from the marvellous to the uncanny; 'what is a hesitation,' he asks, 'if not the continuous tension between the various interpretations? ${ }^{37}$ Todorov himself allows that there are authors, like Kafka who confer 'complete autonomy' on their texts. Agnon, too, falls within this judgment. Indeed, such a text never permits the reader to reach a conclusion regarding the nature of the events within the story. ${ }^{38}$ Ultimately, Oren's 'Anti-metamorphosis', to use Stanislaw Lem's words, sets up 'an undecidability about its own meaning ${ }^{39}$ for there is no focal point within it able to resolve it. ${ }^{40}$ According to Leah Baratz, 'The story leaves us without information about the reason for the central events. The expectation of a "message" to clarify its concealed reasons and purpose is an absurd expectation which leads to nothing., ${ }^{41}$ This vain hope is, in fact, an element of the fantastic not a judgment of it. Inasmuch as 'Anti-metamorphosis' adheres to Todorov's principles of the fantastic-marvellous, the application of them limits the range of questions we are permitted to ask about this, or any similar, text.

On the other hand, I believe that Oren's unpopularity may derive precisely from his ability to write stories that Todorov would define as the 'pure fantastic', about which no questions need or can be asked. My question originally was whether defining Oren's stories according to Todorov's generic system helps us to read them. In my opinion it does. Even if they are not strictly supernatural (few of them are), strange or unnatural events take place in them. The two paradigmatic stories I have discussed are not logically construed as allegories or parables, although they both utilise scientific metaphors, and if they are satires, their object - as indeed with allegory - is too opaque. 'Meaning', as we have seen, is elusive and the reader's hesitation is always required. Therefore applying Todorov's categorisation to Oren's fiction certainly determines the way we read it. I believe this has implications with regard to other Hebrew authors, Agnon in particular, whose reading has been somewhat regulated by established literary norms, and to the work of some younger Israeli experimental writers.

\footnotetext{
${ }^{37}$ Bartana, Hafantasia basifrut dor hamedina, 29.

${ }^{38}$ Miller, The Marvellous and the Fantastic in the Works of Yitzhak Oren, 28.

${ }^{39}$ Stanislaw Lem, 'Todorov's Fantastic Theory of Literature', Science Fiction Studies 1:4 (Fall, 1974), 227-37. http://www.depauw.edu/SFs/backissues/4/lem4art.htm

${ }^{40}$ See George Aichele, Sign, Text, Scripture (London/New York: Continuum International Publishing Group, 1997), 107.

${ }^{41}$ Baratz, Monografiyah al odot Yitzhak Oren (Nadel), 249.
} 


\section{BIBLIOGRAPHY}

George Aichele, Sign, Text, Scripture (London/New York: Continuum International Publishing Group, 1997).

Leah Baratz, Monografiyah al odot Yitzhak Oren (Nadel) (Tel Aviv: Or Am, 2003).

Ortsiyon Bartana, Hafantasia basifrut dor hamedina [Fantasy in the literature of the generation of the state] (Tel Aviv: Papryrus/Hakibbutz Hameuchad, 1989).

Jacqueline Eyring Bixler, 'Freedom and Fantasy: A Structural Approach to the Fantastic in Carballido's Las cartas de Mozar', Latin American Theatre Review (Fall, 1980).

Tova Cohen, 'The maskil as lamdan: the influence of Jewish education on Haskalah writing techniques' in Glenda Abramson and Tudor Parfitt, eds., Jewish Education and Leaning (Reading: Harwood Academic Publishers, 1994), 61-74.

Alex Comfort, Reality and Empathy: Physics, Mind, and Science in the 21st Century (Albany: SUNY Press, 1984).

Ásdís Egilsdóttir, 'The Fantastic Reality: Hagiography, Miracles and Fantasy', http://www.dur.ac.uk/medieval.www/sagaconf/asdis.htm

Franz Kafka, 'The Metamorphosis' (1915). The Metamorphosis, trans. and ed. Stanley Corngold (London/NY: WW Norton, 1996).

Franz Kafka, The Great Wall of China and Other Pieces (London/Edinburgh: Morrison and Gibb Ltd., 1946).

Franz Kafka, Complete Stories, trans. W. and E. Muir (New York: Schocken, 1971).

Edward Kassner, James Newman and James Roy Newman, Mathematics and the Imagination (Dover Publications, 2003).

Sarah Katz, 'Yitzhak Oren, yotser poreh...', Makor rishon (September, 2007).

Max Knight, ed., The Imaginary Number: Short Stories by Yitzhak Oren, trans. various (Berkeley, California: Benmir Books, 1986).

Stanislaw Lem, 'Todorov's Fantastic Theory of Literature', Science Fiction Studies 1:4 (Fall, 1974), 227-37.

Gilead Morahg, 'Israel's New Literature of the Holocaust: The Case of David Grossman's SeE Under: Love', Modern Fiction Studies 45:2 (1999). 
Yitzhak Oren, 'Ha'antimetamorfosis' in Yitzhak Oren, Pnei dor vakelev [The face of a generation and a dog] (Jerusalem: Ogan, 1968), 204-225, trans. Philip Simpson, The Jewish Quarterly (Winter 1989-1990), 14-24.

Gershon Shaked, Hasipporet ha ivrit 1880-1980, 3 (Jerusalem/Tel Aviv: Keter; Hakibbutz Hameuchad, 1988), 168-169.

Tzvetan Todorov, The Fantastic: A Structural Approach to a Literary Genre, trans. Richard Howard and Robert Scholes (Ithaca: Cornell University Press, 1975).

Carter Wheelock, 'Fantastic Symbolism in the Spanish American Short Story', Hispanic Review 48:4 (Autumn, 1980). 